\title{
FIGHT OR FLIGHT: STRES DAN STRATEGI COPING GURU PEMBIMBING KHUSUS
}

\author{
Nouf Zahrah Anastasia
}

\author{
Josephine L. Tobing \\ josephine@yahoo.com
}

\begin{abstract}
Abstrak
Profesi guru bagi anak berkebutuhan khusus yang dikenal dengan sebutan Guru Pendamping Khusus (GPK) tidak lepas dari tekanan stres. Stres dapat berdampak negatif pada kinerja untuk itu GPK perlu mengembangkan suatu strategi coping yang efektif, agar dapat melewati stres yang dialami dan tetap memiliki kualitas kerja yang baik. Penelitian ini bertujuan mengeksplorasi peran dan tanggung jawab GPK, memahami situasi yang menimbulkan stres kerja, dan menganalisis strategi coping dalam menghadapi stres yang timbul. Peneliti menggunakan metode penelitian kualitatif dengan pendekatan fenomenologis. Peneliti menggunakan manajemen resiko sebagai alat analisis untuk memetakan peluang terjadinya stres yang menjadi nature dari profesi pengajar ABK. Mitigasi yang efektif diharapkan dapat meminimalisir dampak stress, baik untuk sumber stress yang terprediksi yang tidak terprediksi. Metode pengambilan sampel adalah strategi purposive sampling yang mencakup 10 guru pendidikan khusus dari 4-unit yang berbeda di Departemen Special Education Sekolah SPK Penyelenggara Pendidikan Inklusif di Jakarta Selatan. Temuan menunjukkan bahwa ada 5 sumber stres kerja yang utama, yaitu (1) kombinasi beban kerja dan tekanan waktu, (2) perilaku tantrum / sulit dari siswa ABK, (3) kurangnya kompetensi guru (pengetahuan / pengalaman / kemampuan dalam mengajar dan menghadapi $\mathrm{ABK}$ ), (4) faktor orang tua siswa (tidak kooperatif/sulit), dan (5) hubungan interpersonal antar rekan guru. Para GPK menggunakan berbagai strategi coping sebagai alat mitigasi dengan pendekatan problem-focused dan emotion-focused sesuai sesuai dengan kondisi yang dialami.
\end{abstract}

Kata kunci: Stres Kerja, Strategi Coping, Guru Pendamping Khusus 


\begin{abstract}
The teacher for children with special needs, known as Special Education teacher, is inseparable from stress. Stress can harm the teacher's performance therefore every Special Education teacher needs to develop an effective coping strategy to overcome the stress experienced. The research is aimed at exploring the roles and responsibilities of special education teachers, understanding the situations in which elicit occupational stress, and analyzing the coping strategies in response to stressors. The researcher uses qualitative research methods with phenomenological approach. The researcher uses risks management as an analysis tool to map out the occurance of the stressors that comes with teaching special needs students. An effective mitigation will hopefully minimize the effect of stress, both for predictable and unpredictable stressors. The sampling method was a purposive sampling strategy which included 10 Special Education teachers from 4 different units in Special Education Department at an inclusive private school in South Jakarta. The findings suggest that there are top 5 major occupational stressors, which namely are (1) combination of workload and time pressure, (2) student's challenging behavior, which can include tantrums and meltdowns, (3) lack of competence (knowledgelexperiencelability) in teaching with students with special needs, (4) difficult and uncooperative parent, and (5) interpersonal relation between colleagues. The Special Education teachers uses a variety of coping strategies as mitigation tool both with a problem-focused and emotion-focused approach in accordance with the conditions experienced.
\end{abstract}

Keywords: Occupational Stress, Special Education Teacher, Coping Strategy 


\section{A. PENDAHULUAN}

Pendidikan merupakan salah satu hak asasi semua manusia, tak terkecuali bagi anak berkebutuhan khusus (selanjutnya disebut ABK). Data BPS tahun 2007 mencatat terdapat 8.3 juta individu berkebutuhan khusus dengan berbagai kondisi di Indonesia (Tarnoto, Permasalahan- Permasalahan Yang Dihadapi Sekolah Penyelenggara Pendidikan Inklusi Pada Tingkat SD, 2016). Hasil Survey Kementerian Kesehatan RI tahun 2013 yang dituliskan dalam Santoso \& Setiawan (2018,

p. 27) tercatat sebanyak $11.7 \%$ (41 juta) penduduk di Indonesia memiliki kebutuhan khusus, baik mereka dengan disabilitas fisik maupun mental.

Konsekuensinya, pendidikan yang berkualitas untuk ABK tentu menjadi kebutuhan yang tidak terbantahkan. Terlebih, pendidikan bagi ABK, secara konstitusional telah diakui, diterima dan dituliskan dalam sistem pendidikan nasional. Pasal 5 Undang-undang No. 20 tahun 2003 tentang Sistem Pendidikan Nasional menyebutkan bahwa setiap warga negara mempunyai hak yang sama untuk memperoleh pendidikan yang bermutu. Selanjutnya, pemerintahpun telah mencanangkan penyelenggaraan pendidikan inklusif yang bertujuan untuk memberikan akses pendidikan bagi semua anak, tak terkecuali ABK, agar mereka berkesempatan belajar tidak hanya di sekolah khusus namun juga di sekolah umum.

Dalam mewujudkan pendidikan inklusif yang bermutu, peran guru menjadi salah satu kunci utama. Peran guru sangat menentukan keberhasilan program belajar yang dijalani oleh siswa. Dalam konteks pendidikan bagi siswa ABK di sekolah yang penyelenggarakan pendidikan inklusif, guru yang dimaksud tidak hanya guru kelas atau guru bidang studi. Terdapat Guru Pendamping Khusus (selanjutnya disebut GPK) yang berperan besar bagi kemajuan belajar siswa ABK. GPK adalah guru yang memiliki kompetensi dan peran khusus berkolaborasi dengan guru kelas dalam mendampingi atau mengajar ABK dalam seting sekolah reguler.

Menurut Peraturan Pemerintah No. 17 tahun 2000 tentang Pengelolaan dan Pengadaan, GPK secara umum memiliki tugas dan tanggung jawab sebagai pendidik profesional membimbing, menilai dan mengevaluasi peserta didik berkelainan pada satuan pendidikan umum, satuan pendidikan kejuruan dan/atau pendidikan keagamaan. GPK diperlukan tidak hanya sebagai guru pendamping untuk $\mathrm{ABK}$ ketika mengikuti pelajaran di kelas reguler, namun juga sebagai pendidik utama ketika ABK belajar sesuai dengan kebutuhannya di kelas khusus.

GPK dihadapkan pada siswa ABK yang memiliki perkembangan berbeda dari siswa pada pada umumnya. Kondisi ABK yang sangat beragam menuntut GPK melakukan berbagai strategi belajar agar ABK bisa memahami materi pelajaran, baik di kelas umum maupun intervensi lanjutan di kelas khusus. Dan hal ini tentulah tidak mudah dijalani. Tantangan mengajar dan menangani siswa ABK dengan beragam kebutuhan serta profil dan karakteristik dapat berpotensi menimbulkan stres. Terlebih lagi jika seorang GPK yang baru bergabung tidak memiliki berlatar belakang linier, atau tidak berasal dari Pendidikan Luar Biasa (PLB). Billingsley (2004) dan juga Whitaker (2003) dalam studi fenomena Alborn-yilek (2010, p. 2) menuliskan GPK menghadapi 
banyak masalah di tahun pertama menjalankan profesi mereka. Kyriacou (2001) dalam Skaalvik \& Skaalvik (2015, p. 182) mendefinisikan stres sebagai pengalaman emosi negatif atau tidak menyenangkan yang dihasilkan dari aspek pekerjaan. Dalam konteks profesi GPK, seorang guru dapat mengalami stres jika tuntutan atau beban pekerjaan tidak sesuai dengan kapasitas yang dirasakan mereka perlu ada untuk memenuhi tuntutan atau nilai-nilai pendidikan yang distandarkan. Beberapa penelitian yang ditulis dalam (Cancio, et al., 2018) menunjukkan bahwa pekerjaan pendidik untuk ABK sulit, menuntut, dan memiliki tingkat stres lebih tinggi daripada pendidik umum (Bettini et al., 2017).

Stres dapat dikenali dari berbagai gejala yang ditunjukkan seseorang. Terry Beehr dan John Newman (dalam Rice, 1999) dalam Zainal, Hadad, \& Ramly (2017, pp. 317-318) menyebutkan tiga gejala stres pada individu, yaitu gejala psikologis, gejala fisiologis, dan gejala perilaku. Sedangkan dampak stres oleh Gibson, Ivancevick, Donnelly dan Konopaske (2012: 197) dalam Wibowo (2013,

p. 198) dikelompokkan menjadi tiga kategori, yaitu dampak pada perilaku, kognitif, dan fisiologis. Ditambahkan oleh Gibson, Ivancevich, Donnelly dan Konopaske, Grifin \& Moorhead (2014, p. 191) terdapat tiga konsekuensi dari stres yaitu individual consequences, organizational consequenses, dan burnout.

Untuk dapat mengelola stres yang ada, perlu diketahui situasi, kondisi atau sumber stres itu sendiri. Colquitt, Lepine, dan Wesson (Colquitt, Lepine, \& Wesson, 2015) yang mengelompokkan stres kerja ke dalam 3 tema besar, yaitu time pressure (tekanan waktu), work responsibility (tanggung jawab kerja) mengacu pada sifat kewajiban yang dimiliki seseorang terhadap orang lain, dan work complexity (kerumitan kerja) mengacu pada sejauh mana persyaratan pekerjaan, dalam hal pengetahuan, keterampilan, dan kemampuan melebihi kemampuan orang yang bertanggung jawab untuk melakukan pekerjaan (Schaubroeck, Ganster \& Kemmerer, 1994). Arismunandar \& Wardhana (1998, p. 4) menuliskan beberapa sumber stres guru dari beberapa penelitian. Siswa yang berkelakuan buruk terus menerus (Feitler \& Tokar, 1982) dan "terlalu banyaknya perkerjaan yang harus diakukan" (Capel, 1992) merupakan sumber stres guru yang paling sering muncul. Sedangkan Forlin (2001) dalam Antoniou \& Katroni (2009, p. 100) telah mengklasifikasikan stres pada guru untuk anak berkebutuhan khusus menjadi tiga kelompok umum, yaitu: (1) administrative (contohnya: beban kerja yang berat, kelebihan peran dan konflik peran, ketidakjelasan peran, kesulitan waktu / sumber daya),

(2) class-bases atau stres yang muncul karena kondisi kelas. Contohnya iklim kelas, rasio tinggi antara guru- murid, kemajuan murid yang terbatas dengan penekanan pada perilaku murid yang sulit dan menantang (Brouwers dan Tomic, 2000; Friedman, 1995; Hock, 1988), dan (3) personal yaitu sumber stres yang berasal dari pribadi guru sendiri; contohnya: kolaborasi yang buruk dengan rekan kerja, lingkungan kerja yang buruk, locus of control eksternal, gaji tidak cukup dan status sosial yang rendah (Borg, Riding dan Falzon, 1991; Byrne, 1994; Guglielmi dan Tatrow, 1998; Kyriacou, 2001; Male dan May, 1997). 
Dalam studi skala besar di Florida (Miller et al., 1999) yang ditulis dalam Billingsley (2004, p.49) ditemukan stres adalah salah satu prediktor paling kuat yang membuat GPK keluar dari pekerjaan mereka. Peneliti lain telah menemukan bahwa stres yang dirasakan para GPK membuat mereka berencana untuk berhenti dari pekerjaan (Billingsley \& Cross, 1992; Cross \& Billingsley, 1994; Gersten et al., 2001; Morvant et al., 1995; Schnorr, 1995; Singh \& Billingsley, 1996).

Kondisi stres yang dialami GPK perlu disikapi dengan strategi coping yang tepat. Coping menurut Lazarus dan Folkman Lazarus \& Folkman (1984, p. 141) adalah constantly changing cognitive and behavioral efforts to manage specific external and/or internal demands that are appraised as taxing or exceeding the resources of the person (upaya kognitif dan perilaku yang digunakan seseorang untuk mengelola diri dari tuntutan eksternal dan / atau yang dinilai melebihi kemampuan seseorang tersebut). Coping berfungsi untuk menunjukkan bentuk penyesuaian diri terhadap situasi yang menimbulkan stres yang cukup berarti bagi individu tersebut. Dengan kata lain, kata coping di sini adalah upaya untuk mengurangi dampak dan memperkecil peluang timbulnya stres. Ketidakmampuan mendaya-gunakan perilaku coping yang tepat dapat membuat guru mengalami stres berkepanjangan yang tentunya kemudian berpotensi menghasilkan rendahnya kualitas dan kuantitas kinerja, menyebabkan konflik internal, kerja sama yang tidak efektif, hubungan internal terganggu dan iklim kerja yang tidak menyenangkan.

Potensi stres dalam pekerjaan dapat dikenali karakteristiknya, sebab dan akibatnya, sehingga dapat diantisipasi, dipikirkan bagaimana menghadapinya. Menjadi penting bagi pekerja dan perusahaan untuk melihat lebih jauh stres yang dialami para pekerjanya, tak terkecuali para stres yang dialami GPK. Menurut Betoret (Betoret, 2006), guru yang memiliki akses untuk melakukan strategi coping cenderung kurang melaporkan stres dan kelelahan dibandingkan mereka yang memiliki strategi coping yang lebih sedikit. Mekanisme coping dapat mengurangi efek stressor dengan mengubah keadaan emosional seseorang selama situasi stres, atau dengan menghilangkan atau mengurangi sumber stres (Lazarus, 1993). Oleh karena itulah, setiap GPK dengan segala beban kerja yang dihadapinya, diharapkan mampu mengatasi stresnya dengan melakukan strategi coping yang efektif agar mereka mampu menjalani pekerjaan dan memiliki kualitas kerja yang baik.

Lazarus \& Folkman (1984) menjelaskan dua metode coping yang dapat dilakukan yaitu problem-focused coping yang lebih pada upaya penyelesaian masalah secara langsung, \& emotion-focused coping atau mengelola emosi yang timbul sebagai akibat dari stres yang dialami. Colquitt, LePine, dan Wesson (2013:146) dalam Wibowo (2017, p. 187) mengatakan bahwa stres merupakan hal yang perlu menjadi perhatian para pengelola ataupun pemimpin perusahaan, karena dapat berdampak pada kinerja dan komitmen karyawan.

Kembali pada konteks GPK, mendidik dan menangani profil ABK yang tidak seperti siswa pada umumnya dengan segala tantangan dan kondisi dari lingkungan, dari diri guru, maupun terkait nature pekerjaan itu sendiri merupakan tugas dan tanggung jawab yang dapat mengakibatkan stres kerja. 
Stres kerja GPK terlebih dirasakan oleh para guru yang baru, terlebih mereka yang tidak memiliki latar belakang Pendidikan Luar Biasa. Berikut adalah hasil wawancara sehubungan dengan stres yang dialami salah seorang GPK.

"Waktu jadi TA awal mulai ngajar, aku benar-benar gak tahu harus apa, karena memang baru banget, zero experience, langsung go show. ... Aku juga takut. Takut gimana caranya menghadapi anak tantrum. Kalau lagi ngadepin mereka tantrum, rasanya kaya, waduh, mati gue, trus ini musti gimana. Aaah. Tolong... dan itu bisa lama baru tenang kalau tidak dibantu guru lain."

Selain guru yang mengalami stress, pihak sekolah juga dapat mendapatkan konsekuensi atas stres yang dialami guru. Untuk itu menjadi penting untuk meneliti situasi, beban kerja maupun memetakan kondisi-kondisi yang mengakibatkan stres kerja pada GPK dalam menjalani peran dan tanggung jawab mereka dan bagaimana mereka mengatasi stres tersebut hingga tugas utama mereka sebagai GPK tetap dapat dipenuhi.

Penelitian ini bertujuan untuk (a) mengeksplorasi beban kerja GPK di sebuah sekolah swasta yang menyelenggarakan pendidikan inklusif, (b) mendapatkan situasi dan kondisi kerja yang mungkin menjadi sumber stres terkait profesi mereka sebagai GPK dan (c) untuk mendapatkan gambaran dan pendekatan strategi coping yang dilakukan para GPK untuk mengatasi stres yang ada. Hasil penelitian ini diharapkan dapat memberikan kontribusi terutama bagi para GPK baru agar dapat mengenali potensi stres yang terkait dengan profesi ini dan mendapatkan masukkan strategi coping efektif yang dapat dilakukan.

\section{B. METODE PENELITIAN}

Pada penelitian ini peneliti menggunakan metode penelitian kualitatif (qualitative research methods) dengan pendekatan fenomenologi. Pendekatan kualitatif ini dipilih karena peneliti membutuhkan informasi dan jawaban yang lebih mendalam dan detail tentang permasalahan yang diteliti. Sedangkan alasan mengapa pendekatan fenomenologi sesuai untuk penelitian ini karena studi fenomenologis bersifat deskriptif serta berupaya untuk memotret berbagai situasi dan persoalan yang ada dalam dunia kehidupan orang-orang secara aktual dengan pengalaman khusus yang dialaminya. Dalam penelitian ini, penelitian kualitatif dengan pendekatan fenomenologi ini dipilih agar peneliti dapat mengeksplorasi pengalaman stres GPK dan bagaimana strategi coping yang dilakukan.

Penelitian dijalankan di sebuah sekolah swasta penyelenggara Satuan Pendidikan Kerjasama (SPK) yang juga menyelenggarakan pendidikan inklusif di wilayah Jagakarsa, Jakarta Selatan (Sekolah SPK Inklusif Jagakarsa). Sekolah ini dipilih karena beberapa alasan, yaitu: merupakan sekolah yang melakukan praktek pendidikan inklusif sejak tahun 1995, memiliki kelengkapan jenjang pendidikan, yaitu TK, SD, SMP, dan SMA dan juga Departemen Special Education dengan 4 unit alternatif layanan pendidikan khusus untuk membantu siswa ABK dengan berbagai kondisi dan kesulitan belajar, memiliki 22 GPK untuk hampir 60 siswa ABK yang belajar di sekolah ini.

Pengambilan sampel dalam penelitian kualitatif ini menggunakan prosedur purposive sampling. Peneliti memilih sepuluh (10) orang GPK Sekolah SPK Inklusif Jagakarsa yang dilibatkan sebagai partisipan penelitian. Seluruh guru yang dipilih berasal dari empat unit layanan pendidikan khusus yang 
ada di Sekolah SPK Inklusif Jagakarsa. Hal ini didasarkan pada pemikiran akan adanya perbedaan nature kerja yang khas dari tiap unit karena karakteristik $\mathrm{ABK}$ yang belajar di tiap unitnya juga memiliki perbedaan seperti usia, tingkat kecerdasaan, dan kemampuan secara umum. Sepuluh partisipan penelitian yang dipilih juga yang memiliki perbedaan pengalaman mengajar, yaitu kurang dari 5 tahun, lebih dari 5 tahun, dan yang tidak lagi menjalani profesi GPK.

Tehnik Pengumpulan Data dan Analisa Data. Metode pengambilan data yang digunakan adalah dengan menggunakan metode qualitative interview. Jenis tehnik wawancara yang dipilih adalah wawancara semi terstruktur yang menggunakan pedoman wawancara. Dilakukan in-dept interview (atau wawancara mendalam) dalam pelaksanaannya. Hal ini dilakukan untuk menemukan permasalahan secara lebih terbuka. Peneliti akan mendengarkan dengan seksama dan melakukan recording dan pencatatan yang diperlukan.

Dalam penelitian fenomenologis, observasi langsung (observasi partisipan/partisipatoris) juga akan dilakukan dalam penelitian ini. Dalam konteks penelitian ini, peneliti ingin mendapatkan gambaran kondisi kerja GPK secara langsung dan tidak mengambil waktu khusus, namun observasi langsung akan dilakukan sejalan dengan penelitian ini dilakukan.

Wawancara pendukung juga dilakukan pada Konselor di Departemen Special Education dan Human Resources Manager Sekolah SPK Inklusif Jagakarsa. Wawancara pendukung ini dilakukan untuk mendapatkan data penunjuang yang diperlukan yang dapat melengkapi data utama yang didapat dari GPK. Selain itu, dilakukan pengumpulan dokumen yang ada berupa deskripsi kerja, catatan kinerja, peraturan yang diperoleh dari Human Resources Manager maupun dokumen yang dimiliki peneliti selaku Head of Special Education Departement untuk melengkapi data penelitian. Sejumlah jurnal penelitian sejenis juga digunakan sebagai pelengkap data yang didapatkan dari hasil wawancara. Saat melakukan wawancara dengan para partisipan penelitian, Teknik Analisis Selama di Lapangan Model Miles dan Huberman dilakukan agar data yang didapat menjadi lebih lengkap. Dalam Sugiono (2015, p. 404) dijelaskan pendapat Miles \& Hugerman (1984) bahwa aktivitas dalam analisis data kualitatif dilakukan secara interaktif dan berlangsung terus menerus sampai tuntas. Jadi dapat dikatakan, peneliti melakukan tahapan analisis data tidak hanya setelah wawancara selesai, namun juga selama wawancara dilakukan. Ketika wawancara masih berlangsung peneliti sudah melakukan analisis terhadap jawaban partisipan penelitian. Jika jawaban dirasa belum memuaskan atau menjawab pertanyaan, pertanyaan lanjutan dilontarkan kembali, sampai data yang dianggap kredibel diperoleh.

Setelah semua data yang dibutuhkan diperkirakan telah terkumpul, peneliti kemudian melakukan analisis data dengan menggunakan metode analisis Colaizzi (1978) untuk mendapatkan hasil penelitian. Adapun langkahlangkah yang digunakan untuk menganalisis hasil penelitian adalah sebagai berikut: (a) membuat uraian lengkap dalam bentuk tulisan lengkap berdasarkan hasil wawancara yang telah dilakukan, (b) peneliti kemudian membaca seluruh transkrip berulang-ulang, (c) peneliti melakukan reduksi data. Peneliti memilih jawaban yang bermakna dan terkait langsung dengan 
tujuan penelitian. Kemudian, jawaban yang telah dipilih dirangkum dipilih untuk kemudian dicari tema dan polanya, (d) peneliti melakukan kategorisasi. Data yang ada dikelompokkan dan diberi tema berdasarkan kesamaan data, (e) menyusun tabel kisi-kisi tema yang membuat pengelompokan ketegori ke dalam tema, sub tema, dan kelompok tema, (f) menuliskan tema hasil penelitian kepada partisipan untuk pengecekan ulang, dan (g) membuat analisa dan menyusun temuan mengenai gambaran umum stres terkait perkerjaan sebagai GPK dan strategi coping yang dilakukan yang didapatkan dari data yang diperoleh. Hasil akhir analisa adalah deskripsi dari fenomena yang diteliti.

\section{HASIL DAN PEMBAHASAN}

Sebelum masuk ke dalam stres kerja GPK yang menjadi partisipan penelitian, penting untuk diketahui kondisi dan nature kerja GPK untuk mendapatkan pemahaman yang lebih menyeluruh akan situasi yang ada.

Alternatif Layanan Pendidikan Khusus. Para partisipan penelitian bekerja di sebuah sekolah SPK di Jagakarsa yang menyelenggarakan praktek pendidikan inklusif untuk jenjang pendidikan mulai dari TK hingga SMA. Sebagai sekolah yang menyelenggarakan praktek pendidikan inklusif, SPK Inklusif Jagakarsa memiliki 4 unit layanan pendidikan khusus untuk memfasilitasi kebutuhan pendidikan siswa ABK. 4 layanan tersebut memberikan pelayanan berbeda sesuai dengan profil dan karakteristik siswa ABK yang ada. Alternatif Layanan Pendidikan di Departemen Special Education adalah sebagai berikut terangkum dalam tabel berikut:

Tabel 1. Alternatif Layanan Pendidikan untuk siswa ABK di Departemen Special Education

Sekolah SPK Inklusif Jagakarsa

\begin{tabular}{|c|c|c|}
\multicolumn{4}{|c}{ Departemen Special Education Sekolah SPK Inklusif Jagakarsa } \\
\hline $\begin{array}{c}\text { Jenjang } \\
\text { pendidikan }\end{array}$ & Kondisi ABK & Alternatif Layanan Pendidikan Khusus \\
\hline \multirow{2}{*}{ Jenjang } & $\begin{array}{c}\text { gangguan perkembangan berat, memiliki } \\
\text { tingkat intelektual jauh di bawah rata- } \\
\text { rata, dan membutuhkan dukungan sedang } \\
\text { hingga maksimal dari guru. }\end{array}$ & Unit Special Needs (SN) \\
\cline { 2 - 4 } & $\begin{array}{c}\text { gangguan perkembangan sedang- ringan, } \\
\text { dan memiliki tingkat intelektual jauh di } \\
\text { bawah rata-rata hingga rata-rata. }\end{array}$ & Unit Learning Centre (LC) \\
\hline \multirow{2}{*}{ Jenjang } & $\begin{array}{c}\text { gangguan perkembangan berat, memiliki } \\
\text { tingkat intelektual jauh di bawah rata- } \\
\text { rata, dan membutuhkan dukungan sedang } \\
\text { hingga maksimal dari guru. }\end{array}$ & Unit Transition Education Centre for High Support Unit \\
\cline { 2 - 3 } SMP - SMA & $\begin{array}{c}\text { gangguan perkembangan sedang-ringan, } \\
\text { yang memiliki tingkat intelegensi jauh di } \\
\text { bawah rata-rata hingga rata-rata. }\end{array}$ & Unit Transition Education Centre for High Functioning \\
Unit (TEC HF)
\end{tabular}

Profil \& Karakteristik ABK. Sebagian gambaran profil \& karakteristik ABK yang diakomodasi di Departemen Special Education Sekolah Inklusif Jagakarsa secara umum tergambarkan dalam petikan wawancara dengan salah satu partisipan sumber penelitian berikut: "Kalau karakter anakanaknya, anak-anak di TEC High Support ini usia kelas 7 sampai kelas 12 - jadi kelas 1 SMP sampai 3 SMA. IQ-nya di bawah 70. Rata-rata murid saya IQ-nya 60 ke bawah. Kemampuan belajarnya maksimum setara kelas 3 SD. Dan, untuk hal lain mereka rata-rata ya harus 
dibantu banyak. Bahkan ada yang baru belajar membaca di usianya yang sudah 13 tahun. Masih banyak yang tantrum (mengamuk, marah dengan ledakan emosi yang besar). Pemahaman juga sangat kurang. Dari sosialnya, mereka banyak ngga paham hal- hal yang terjadi. Jadi beberapa juga masih tantrum, masih banyak ngga ngerti. Jadi perlu berbagai cara untuk membuat mereka dapat memahami satu hal." Hasil rangkuman profil \& karakteristik siswa ABK yang dilayani di Sekolah SPK Inklusif Jagakarsa dapat dilihat dalam tabel berikut:

Tabel 2. Rangkuman Profil \& Karakteristik ABK di Departemen Special Education Sekolah SPK Inklusif Jagakars

\begin{tabular}{|c|c|}
\hline & $\begin{array}{l}\text { TEC } \\
\text { HF }\end{array}$ \\
\hline Usia ABK & $\begin{array}{cccc}5-13 & 5-13 & 13-18 & \mathbf{1 3 - 1 8} \\
\text { tahun } & \text { tahun } & \text { tahun } & \text { tahun }\end{array}$ \\
\hline Diagnosa & $\begin{array}{c}\begin{array}{c}\text { Anak dengan gangguan perkembangan ringan- } \\
\text { berat, termasuk di dalamnya: Gangguan Spektrum } \\
\text { Autisme }\end{array} \\
\text { Attention Deficit Disorder (Gangguan Pemusatan } \\
\text { Perhatian), } \\
\text { Attention-Deficit Hyperactivity Disorder (Gangguan Pemusatan } \\
\text { Pehatian dan Hiperaktivitas) } \\
\text { Specific Learning Disability (Gangguan Belajar } \\
\text { Spesifik), } \\
\text { Slow learner (Lamban belajar), } \\
\text { Speech \& Language Disorder (Gangguan } \\
\text { Perkembangan Wicara dan Bahasa), Global } \\
\text { Developmental Delay (Keterlambatan } \\
\text { Perkembangan Global), Sensory Processing } \\
\text { Disorder (Gangguan Pemrosesan Sensorik), dsb. }\end{array}$ \\
\hline $\begin{array}{l}\text { Tingkat } \\
\text { Intelegensi }\end{array}$ & $\begin{array}{cccc}\text { IQ } & 70< & \text { IQ ABK } & \mathbf{7 0 <} \\
\text { ABK } & \text { IQ } & <70 & \text { IQ } \\
<70 & \text { ABK } & & \text { ABK }\end{array}$ \\
\hline $\begin{array}{l}\text { Implikasi } \\
\text { dalam } \\
\text { bidang } \\
\text { akademik }\end{array}$ & $\begin{array}{l}\text { - Mengalami kesulitan memahami materi, guru perlu menjalankan } \\
\text { strategi khusus \& structured teaching untuk membantu ABK } \\
\text { memahami materi yang disampaikan. } \\
\text { Kurikulum yang berlaku umum perlu dimodifikasi dan diberikan } \\
\text { akomodasi yang diperlukan, baik dari segi konten, bahan dan } \\
\text { pengajaran, alat bantu ajar, evaluasi, dan laporan hasil, lingkungan } \\
\text { belaja sesuai dengan kemampuan kognitif siswa serta kebutuhan } \\
\text { sosial dan emosional mereka dan dituliskan dalam Program } \\
\text { Pembelajaran Individual (PPI) } \\
\text { Materi pelajaran yang diberikan didahulukan yang bersifat } \\
\text { fungsional, dan khususnya untuk ABK dengan gangguan berat, } \\
\text { dilakukan dengan praktek langsung. }\end{array}$ \\
\hline $\begin{array}{c}\text { Implikasi } \\
\text { dalam } \\
\text { bidang } \\
\text { sosial }\end{array}$ & $\begin{array}{l}\text { Rata-rata ABK menunjukkan hal-hal berikut di bawah ini bervariasi } \\
\text { sesuai dengan jenis gangguan, tingkat intelegensi dan karakter } \\
\text { individu masing-masing: } \\
\text { Pemahaman yang minim akan } \\
\text { norma sosial, bahaya } \\
\text { Kemampuan sosial dan } \\
\text { komunikasi yang terbatas }\end{array}$ \\
\hline
\end{tabular}




\begin{tabular}{|c|c|c|c|c|}
\hline \multirow[b]{2}{*}{$\begin{array}{l}\text { Implikasi } \\
\text { dalam } \\
\text { kemampu } \\
\text { an } \\
\text { kemandiri } \\
\text { an diri }\end{array}$} & \multicolumn{4}{|c|}{$\begin{array}{c}\text { Mudah frustasi karena tidak paham akan } \\
\text { tuntutan lingkungan Sering kali } \\
\text { menggunakan cara tantrum untuk } \\
\text { mendapatkan sesuatu } \\
\text { membutuhkan dukungan orang lain untuk bisa } \\
\text { memahami tugas }\end{array}$} \\
\hline & $\begin{array}{l}\text { Membutuhk } \\
\text { an dukungan } \\
\text { penuh dari } \\
\text { orang lain }\end{array}$ & $\begin{array}{l}\text { Cukup bisa } \\
\text { dilatih } \\
\text { kemandirian } \\
\text { dan } \\
\text { diandalkan, } \\
\text { walau perlu } \\
\text { supervisi } \\
\text { orang } \\
\text { dewasa }\end{array}$ & $\begin{array}{l}\text { Membutuhk } \\
\text { an dukungan } \\
\text { penuh dari } \\
\text { orang lain }\end{array}$ & $\begin{array}{l}\text { Cukup } \\
\text { bisa } \\
\text { diandalka } \\
\text { n walau } \\
\text { tetap } \\
\text { perlu ada } \\
\text { pengawas } \\
\text { an dari } \\
\text { orang } \\
\text { tua/orang } \\
\text { dewasa }\end{array}$ \\
\hline
\end{tabular}

Tanggung Jawab, Beban Kerja dan Latar Belakan Pendidikan GPK.

Berdasarkan hasil wawancara dengan ke-10 (sepuluh) partisipan penelitian, tersebutkan deskripsi tugas dan tanggung jawab GPK secara umum yang meliputi (1) perencanaan \& pengembangan Program Pembelajaran Individual (PPI), (2) menerapkan dan mengelola proses belajar-mengajar, dan (3) membuat laporan perkembangan belajar seperti tergambar dalam diagram berikut. Tentunya untuk tiap tanggung jawab tersebut terdapat detil tugas yang harus dipenuhi oleh setiap GPK. Jam kerja GPK di Sekolah SPK Inklusif Jagakarsa adalah dari jam 7:30 hingga pukul 16:00. Jam mengajar bagi ABK tingkat SD dimulai pukul 8:00 dan berakhir pukul 14:00. Bagi GPK yang mengajar ABK tingkat SMP dan SMA, pelajaran dimulai pukul 7:30 dan selesai pukul 14:30 untuk SMP dan pukul 15:00 untuk jenjang SMA. Tiap GPK melakukan tatap muka (termasuk mengajar di kelas khusus maupun mendampingi siswa di kelas reguler) sebanyak 35-40 periode belajar tiap minggunya. Ilustrasi tugas, tanggung jawab, dan beban mengajar GPK di Sekolah SPK Inklusif Jagakarsa dari empat unit yang berbeda ditampilkan sebagai berikut:

Tabel 3. Tugas dan Tanggung Jawab Guru SE Sekolah SPK Inklusif Jagakarsa

\begin{tabular}{|c|c|c|c|c|}
\hline \multicolumn{2}{|r|}{ Tugas dan Tanggung Javab guru SE SPK Inklusif Jagakarsa } & \multicolumn{3}{|c|}{ Beban Kerja } \\
\hline $\begin{array}{l}\text { Tanggung } \\
\text { Jawab }\end{array}$ & Deskripsi Tugas & Jam Kerja & Jam Mengajar & $\begin{array}{c}\text { Jumlah beban } \\
\text { mengajar }\end{array}$ \\
\hline $\begin{array}{c}\text { Perencanaan \& } \\
\text { Pengembangan } \\
\text { Program } \\
\text { Pembelajaran }\end{array}$ & $\begin{array}{l}\text { Berkolaborasi dengan rekan guru untuk: } \\
\text { Membuat Program Pembelajaran Individual (PPI) } \\
\text { Merancang urutan pembelajaran sesuai PPI } \\
\text { Menerapkan urutan pembelajaran sesuai PPI } \\
\text { Mengevaluasi proses belajar siswwa sestuai PPI } \\
\text { Menyiapkan rencana pembelajaran dan bahan ajar sesuai dengan PPI } \\
\text { Menentukan perubahan program yang dibutuhan } \\
\text { Menentukan program integrasi } \\
\text { Mentabulasi \& mendokumentasikan program pengajaran yang dilakukan } \\
\end{array}$ & \multirow{3}{*}{$07: 30-16: 00$} & \multirow[t]{3}{*}{$\left|\begin{array}{c}\text { SN \& LC: } \\
\text { 08:00 - } 14: 00 \\
\text { TEC HS: } \\
\text { 08:00 - } 14: 30\end{array}\right|$} & \multirow{3}{*}{$\begin{array}{c}\text { SN: } 35 \\
\text { sesiminggu } \\
\\
\text { LC: } \\
30-35 \\
\text { sesiminggu } \\
\\
\text { TEC HF: } \\
35-40 \\
\text { sesiminggu }\end{array}$} \\
\hline $\begin{array}{c}\text { Menerapkan } \\
\text { dan mengelola } \\
\text { proses belajar- } \\
\text { mengajar }\end{array}$ & $\begin{array}{l}\text { Mengajar semua domain kurikum sesuai PPI } \\
\text { Mengajar ABK menggunakan pengajaran terstrukkur dengan metode pengajaran yang tepat } \\
\text { Mendokumentasikan / membuat catatan perkembangan } \mathrm{ABK} \\
\text { Membuat catatan dan menganalisis temuar/data untuk perencanaan pengajaran lanjutan } \\
\text { Mempersiapkan ABK untuk dapat mengikuti program belajar di kelas reguler }\end{array}$ & & & \\
\hline $\begin{array}{c}\text { Membuat } \\
\text { laporan } \\
\text { perkembangan }\end{array}$ & $\begin{array}{l}\text { Mendokumentasikan performa belajar } \mathrm{ABK} \\
\text { Menulis laporan perkembangan } \mathrm{ABK}\end{array}$ & & & \\
\hline
\end{tabular}


Secara umum berdasarkan wawancara ditemukan bahwa kebanyakan GPK tidak berlatar belakang linier (bukan lulusan Pendidikan Luar Biasa). Namun, mereka semua bertanggung jawab tidak hanya sebagai pendamping siswa ABK belajar di kelas reguler, namun juga untuk mengajar banyak mata pelajaran dengan beban mengajar yang maksimal. Hal ini mengingat profil dan karakter siswa ABK yang tidak semuanya cocok atau dapat belajar di kelas reguler.

“... Matematika, Bahasa Indonesia, Bahasa Inggris. Lalu, karena di sini muridnya anak-anak besar, jadi banyak keterampilan diajarkan dari segi ilmu-ilmu vokasi yang fungsional termasuk pelajarannya pun yang functional."

"Sebagai guru, kita mengajar 8-9 period per hari. Seminggu kita full ngajar. Mulai dari 7.30 pagi-

2.30. Semester lalu 2 period. Hanya ada 45 menit waktu preparation.

Karena jadwal padat. Belum lagi karena aku jadi koordinator unit."

"Kita masuk dari jam 7:30 sampai jam 16:00, beban kerja mengajarnya sendiri, padet. Dari jam 08:00

- 14:00. Itu terus menerus dengan anak."

Stres dan Sumber Stres. Beban kerja dan tanggung jawab GPK yang berat, profil ABK yang memiliki perilaku yang sulit membuat kondisi GPK memiliki peluang tinggi untuk mengalami stres. Menjalani beban kerja yang maksimal dan nature kerja yang unik, para partisipan penelitian mengalami stress yang dapat dikenali dari berbagai gejala yang timbul. Para partisipan penelitian menunjukan gejala dan dampak stres, baik pada perilaku, psikologis maupun fisiologis. Secara psikologis, sebagian dari mereka merasakan kecemasan, ketegangan, kebingungan, mudah tersinggung, merasa mudah marah, sensitif, kelelahan, kehilangan konsentrasi merasa bersalah, merasa tidak berdaya, takut, merasa tidak mampu mengerjakan tugas, lebih sensitif, tegang, lebih mudah marah/tersinggung, cemas, kelelahan, kebingungan, tidak percaya diri dan/atau kewalahan atas berbagai stres yang dialami masing-masing mereka. Beberapa lagi dari mereka menunjukkan gejala fisiologis seperti jantung berdebar-debar, menurunnya tekanan darah, gangguan lambung, kelelahan secara fisik, sakit kepala, gangguan tidur, dan muntah-muntah. Sedangkan gejala perilaku timbul seperti kurang fokus dalam percakapan yang dilakukan atau lebih sering mengeluh.

Hasil penelitian berhasil mengidentifikasi 16 sumber stres yang dirasakan oleh para partisipan penelitian yaitu: interaksi dan pengawasan yang terus menerus, beban tanggung jawab atas keselamatan ABK, baban kerja yang maksimal), pembuatan program individual, kombinasi beban kerja dan tekanan waktu, penuntasan dan pencapaian target belajar sesuai PPI, kompetensi GPK yang belum memadai, ABK sulit menerima pelajaran, perilaku tantrum/sulit $\mathrm{ABK}$, tugas-tugas tambahan diluar jam mengajar, konflik / kolaborasi dengan rekan guru, sikap, tuntutan orang tua yang sulit, persiapan mengajar yang terbatas, dan asesmen untuk sebagai dasar pembuatan PPI. Ke 16 sumber stres yang terdata sebagai hasil penelitian 
kemudian dikategorikan sebagai berikut:

Diagram 1. Sumber-sumber Stres ke-10 Partisipan Penelitian
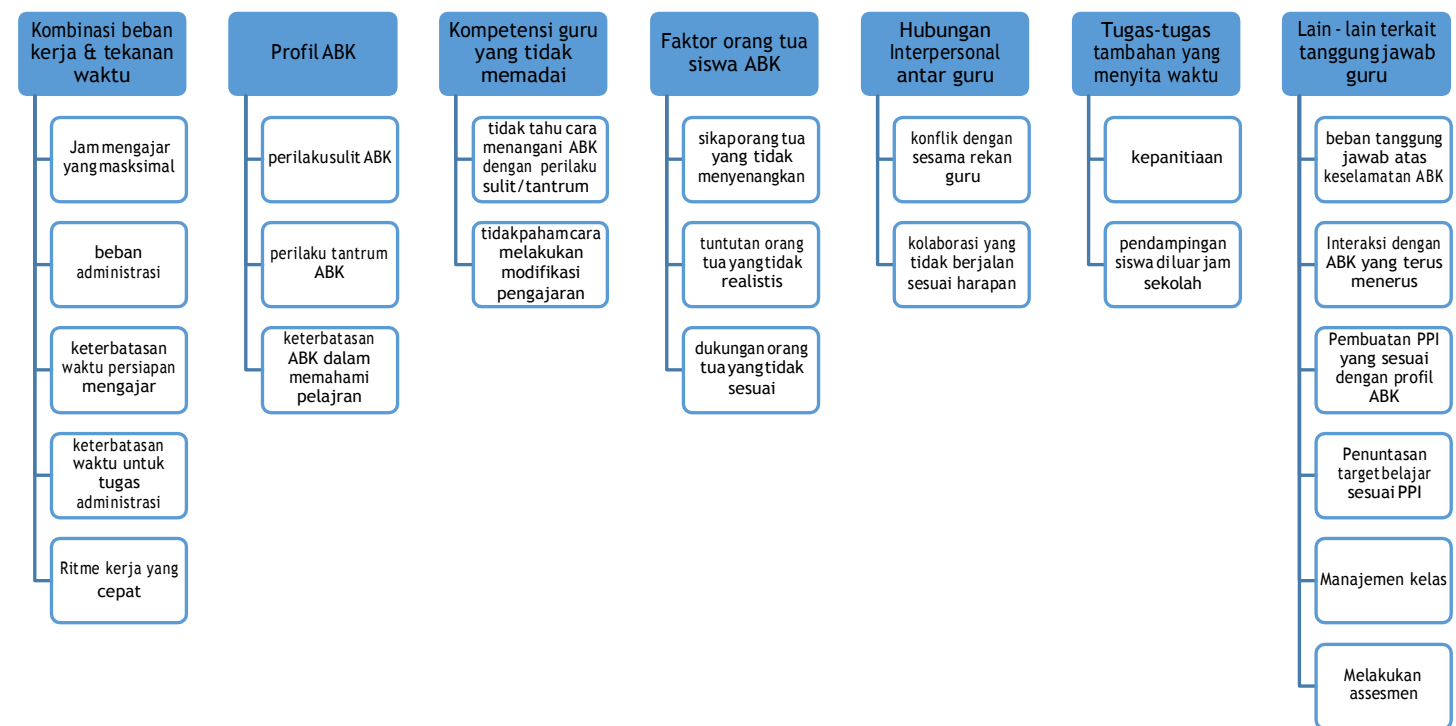

Gambar berikut mengilustrasikan peluang terjadinya tujuh sumber stres utama dan besarnya dampak yang dirasakan oleh para partisipan penelitian sebelum strategi coping dilakukan oleh para partisipan penelitian.

Gambar 4. Sumber Stres, Peluang Terjadinya Stres, dan Dampak Stres Kerja GPK

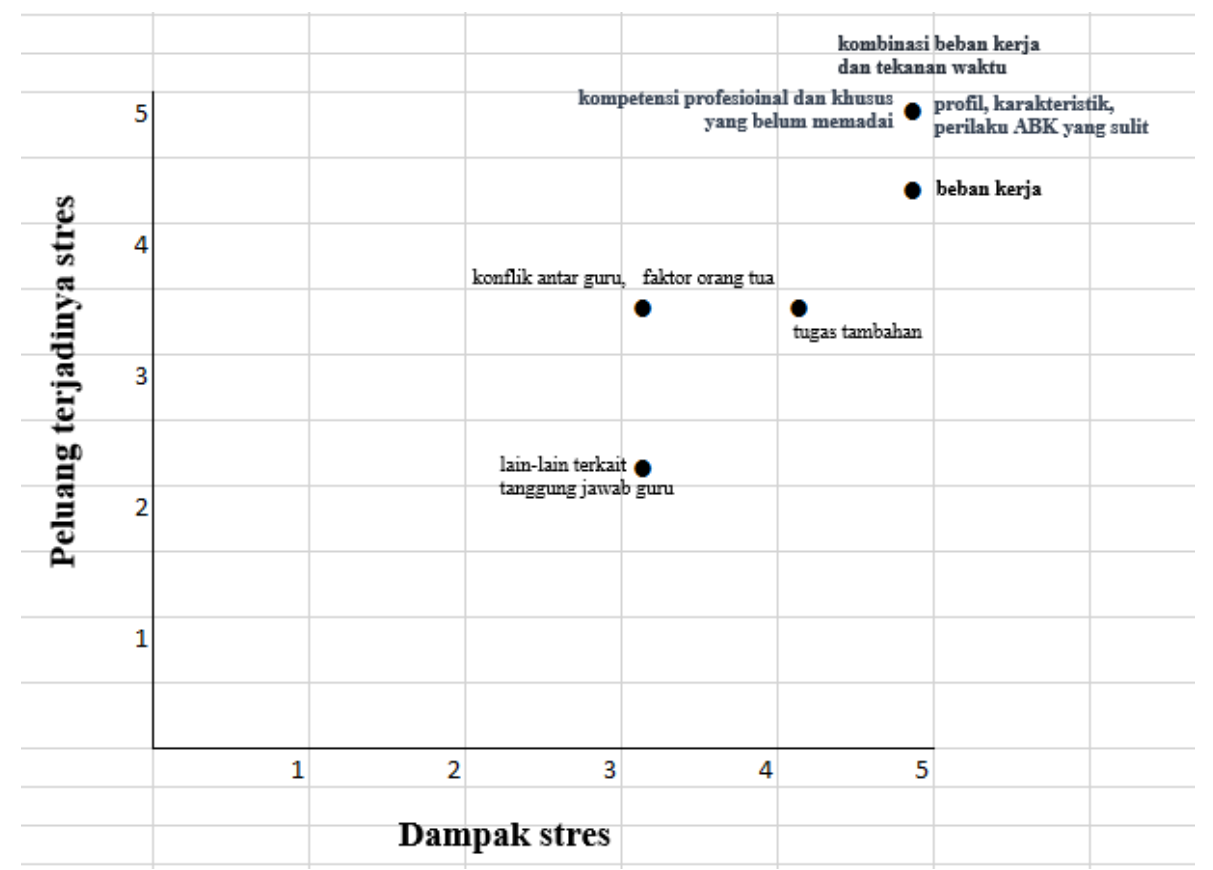

Sebagai hasil akhir peneliti mengkategorisasi dan mengidentifikasi 5 sumber stres utama yang dirasakan oleh guru SE Sekolah Inklusif Jagakarsa. Ke 5 sumber stres tersebut adalah 1) kombinasi beban kerja (beban mengajar, beban administratif, tugas-tugas tambahan) dan tekanan waktu, 2) Profil/karakteristik/perilaku tantrum/sulit dari siswa ABK, 3) Kurangnya kompetensi GPK (pengetahuan/ ketrampilan/pengalaman yang 
belum/kurang memadai dalam mengajar dan menangani siswa $A B K), 4$ ) Faktor orang tua (orang tua yang tidak kooperatif, tuntutan orang tua yang tidak sesuai dengan kondisi, sikap \& perilaku orang tua), dan 5) hubungan interpersonal antara rekan GPK (konflik antar guru).

Strategi coping. Rangkuman strategi coping guru terhadap 5 sumber stres utama dapat dilihat dari tabel 5 berikut:

Tabel 5. Strategi coping sumber stres utama

\begin{tabular}{|c|c|c|}
\hline Sumber Stres & $\begin{array}{l}\text { Strategi Coping: } \\
\text { Problem-focused }\end{array}$ & $\begin{array}{l}\text { Strategi Coping: } \\
\text { Emotion-Focused }\end{array}$ \\
\hline \multirow[t]{4}{*}{$\begin{array}{l}\text { Kombinasi } \\
\text { beban kerja } \\
\text { dan tekanan } \\
\text { waktu }\end{array}$} & $\begin{array}{l}\text { 1. Menuliskan skala prioritas, } \\
\text { termasuk memilih hal-hal yang } \\
\text { perlu ditindaklanjuti dan hal- } \\
\text { hal yang tidak diperhatikan. } \\
\text { 2. Membuat daftar tugas yang } \\
\text { perlu dipenuhi setiap harinya. } \\
\text { 3. Disiplin dengan target yang } \\
\text { dibuat setiap harinya (fokus } \\
\text { dalam penyelesaian tugas). } \\
\text { 4. Menggunakan waktu pribadi } \\
\text { untuk menyelesaikan tugas } \\
\text { (bangun/datang lebih pagi, } \\
\text { menggunakan waktu istirahat di }\end{array}$ & $\begin{array}{l}\text { Melakukan kegiatan yang disukai } \\
\text { / memunculkan rasa senang } \\
\text { (menghabiskan waktu bersama } \\
\text { keluarga, pergi jalan-jalan/makan } \\
\text { dengan rekan guru, menonton } \\
\text { film, menari, mendengarkan } \\
\text { music, bernyanyi, berolah raga, } \\
\text { dsb). }\end{array}$ \\
\hline & \multirow{3}{*}{$\begin{array}{l}\text { sekolah, pulang lebih malam } \\
\text { untuk menyelesaikan persiapan } \\
\text { mengajar/tugas lainnya, atau } \\
\text { mengerjakan tugas di rumah) } \\
\text { 5. Melakukan koordinasi dengan } \\
\text { atau meminta bantuan dari guru } \\
\text { lain (untuk mencari peluang } \\
\text { mengerjakan tugas yang belum } \\
\text { selesai). harapan } \\
\text { 6. Menyesuaikan dalam } \\
\text { (bersikap realistis bratan } \\
\text { membuat program belajar) } \\
\text { 7. Meminta perpanjangan batas } \\
\text { akhir pengumpulan tugas. }\end{array}$} & $\begin{array}{l}\begin{array}{l}\text { Berusaha tidak memikirkan } \\
\text { pekerjaan saat akhir pekan } \\
\text { (contoh: me-nonaktifkan HP, } \\
\text { tidur) }\end{array} \\
\text { Menceritakan beban kerja yang } \\
\text { dijalani pada orang lain (keluarga, } \\
\text { sahabat) } \\
\text { Mundur sejenak dari situasi yang } \\
\text { membuat kewalahan. }\end{array}$ \\
\hline & & $\begin{array}{l}\text { Merasionalisasi kondisi yang ada } \\
\text { dengan mengatakan pada diri } \\
\text { sendiri, "Seorang GPK memang } \\
\text { harus mau melakukan extra } \\
\text { miles" }\end{array}$ \\
\hline & & Mengatur waktu tidur \\
\hline $\begin{array}{l}\text { Profil, } \\
\text { Karakteristik, }\end{array}$ & $\begin{array}{lll}\text { Konsultasi } & \text { dengan } & \text { rekan } \\
& \text { guru } & \text { yang } \\
& \text { lebih berpengalaman }\end{array}$ & $\begin{array}{l}\text { Self-talk untuk menenangkan diri } \\
\text { ketika menghadapi perilaku sulit } \\
\text { ABK }\end{array}$ \\
\hline Perilaku & $\begin{array}{l}\text { Terus mempelajari karakter siswa } \\
\text { ABK }\end{array}$ & \multirow{3}{*}{$\begin{array}{l}\text { Menerima kondisi siswa ABK } \\
\text { sepenuhnya } \\
\text { Melakukan rasionalisasi terhadap } \\
\text { perilaku siswa ABK (tidak } \\
\text { mungkin siswa ABK terus } \\
\text { menerus bisa berperilaku baik, } \\
\text { karena memang karakteristik dan } \\
\text { profilnya) }\end{array}$} \\
\hline \multirow[t]{2}{*}{ yang sulit } & $\begin{array}{l}\text { Meminta contoh / mendapatkan } \\
\text { (modeling) dalam menangani } \\
\text { siswa ABK pada guru yang lebih } \\
\text { berpengalaman }\end{array}$ & \\
\hline & $\begin{array}{l}\text { Terus memberanikan dan } \\
\text { mencoba menangani perilaku sulit } \\
\text { siswa ABK untuk menambah } \\
\text { pengalaman dan jam mengajar. }\end{array}$ & \\
\hline
\end{tabular}




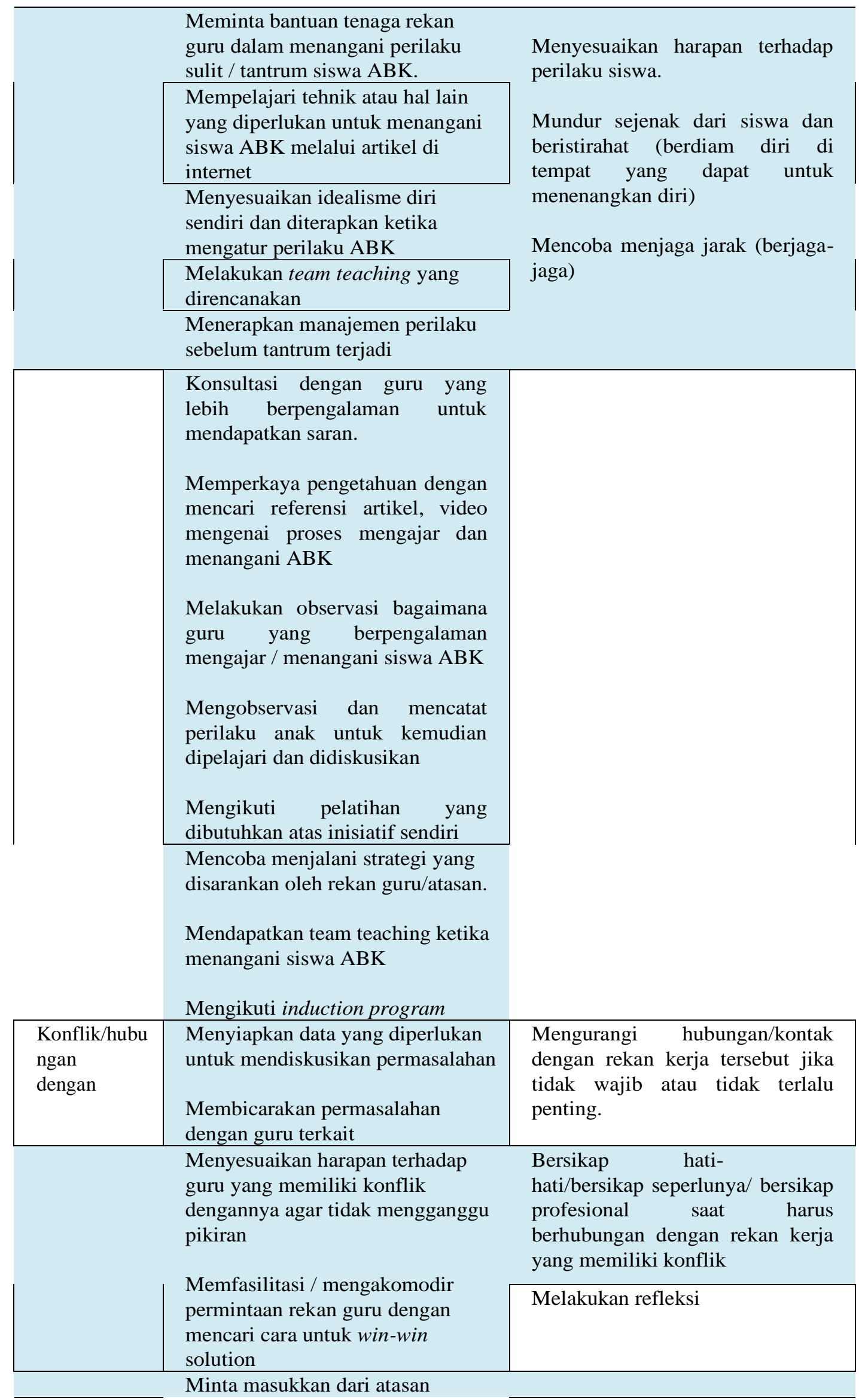




\begin{tabular}{|c|c|c|}
\hline & & $\begin{array}{l}\text { Membuat catatan/pesan tertulis } \\
\text { dalam berkomunikasi untuk } \\
\text { menghindari respon negatif yang } \\
\text { tidak diinginkan dari rekan guru }\end{array}$ \\
\hline & & $\begin{array}{l}\text { Mencoba berfikir positif tentang } \\
\text { apa yang disampaikan / dilakukan } \\
\text { rekan guru terhadap dirinya }\end{array}$ \\
\hline \multirow[t]{5}{*}{$\begin{array}{l}\text { Sikap, } \\
\text { Perilaku } \\
\text { orang tua } \\
\text { yang tidak } \\
\text { mendukung }\end{array}$} & $\begin{array}{l}\text { Mendiskusikan dengan tim guru } \\
\text { untuk mendapat masukkan } \\
\text { penyelesaian masalah } \\
\text { Konsultasi dengan atasan }\end{array}$ & $\begin{array}{l}\text { Mencoba memahami kondisi } \\
\text { orang tua yang memiliki anak } \\
\text { berkebutuhan khusus (berempati, } \\
\text { maklum, menerima) }\end{array}$ \\
\hline & $\begin{array}{l}\text { Menuliskan / membuat daftar hal- } \\
\text { hal yang ingin dibicarakan dengan } \\
\text { orang tua (menghadapi orang tua } \\
\text { dengan data) }\end{array}$ & $\begin{array}{l}\text { Mengelola emosi agar tidak } \\
\text { timbul emosi negatif yang dapat } \\
\text { berdampak pada siswa }\end{array}$ \\
\hline & $\begin{array}{l}\text { Membaca ulang materi yang ingin } \\
\text { disampaikan sebelum } \\
\text { membicarakan dengan orang tua }\end{array}$ & $\begin{array}{l}\text { Mencari tahu apa yang mungkin } \\
\text { sedang terjadi di rumah untuk } \\
\text { memahami kondisi anak dan ortu } \\
\text { secara lebih mendalam (mencoba } \\
\text { berempati) }\end{array}$ \\
\hline & & $\begin{array}{l}\text { Bercerita pada atasan atau } \\
\text { konselor untuk mengeluarkan } \\
\text { emosi negatif yang didapat }\end{array}$ \\
\hline & & $\begin{array}{l}\text { Mengatakan pada diri sendiri } \\
\text { bahwa telah mencoba mengatakan } \\
\text { fakta dan menyarankan. } \\
\text { Selebihnya saya tidak bisa } \\
\text { memaksakan hasil dan tanggung } \\
\text { jawab saya berhenti di situ. }\end{array}$ \\
\hline
\end{tabular}

\section{KESIMPULAN DAN SARAN}

\section{Kesimpulan}

Penelitian ini merupakan upaya untuk mengeksplorasi stres kerja dan faktor-faktor yang menyebabkan Guru Pembimbing Khusus (GPK) perlu melakukan strategi coping dalam menjalani tugas dan tanggung jawabnya sebagai pendidik untuk siswa ABK. Stres yang dialami oleh GPK termanifestasi dalam berbagai gejala psikologis dan fisiologis, baik yang dirasakan oleh guru itu sendiri (misalnya perasaan bersalah, perasaan tidak mampu/berdaya), maupun yang bisa diamati oleh orang lain. Dampak atau konsekuensi dari stres dialami oleh GPK itu sendiri, yang mempengaruhi perilaku mereka (seperti menjadi mudah marah atau tersinggung dengan perkataan rekan guru lainnya), kondisi psikologis (misalnya: gelisah dan mengalami sulit tidur), dan kondisi kesehatan/medis (misalnya: gangguan maag yang berulang dan mual).

Hasil penelitian berhasil mengidentifikasi sepuluh sumber stres GPK di Sekolah SPK Inklusif Jagakarsa dan mengkonfirmasi penelitian penelitian terkait stres kerja pada guru untuk anak berkebutuhan khusus sebelumnya. Lima dari sepuluh stres yang diidentifikasi merupakan sumber stres yang paling dominan diungkapkan oleh seluruh GPK yang menjadi 
partisipan penelitian. Kombinasi beban kerja dan tekanan waktu ditemui sebagai salah satu faktor utama yang memberikan tekanan stres pada guru. Selanjutnya, hasil penelitian menunjukkan profil, karakteristik, dan perilaku ABK yang sulit, pengetahuan, keterampilan, maupun pengalaman mengajar dan menangani ABK yang tidak/kurang memadai, konflik/hubungan kerja antar guru, dan faktor orang tua, seperti tuntutan yang tidak realistis atau sikap atau perilaku orang tua yang tidak kooperatif merupakan kondisi yang membuat para GPK merasa tertekan hingga mengalami stres. Sedangkan lima sumber stres lainnya yang kurang dominan namun dirasakan paling tidak empat hingga lima dari sepuluh partisipan yang diwawancarai adalah tugas-tugas tambahan, beban kerja yang maksimal, ritme kerja yang cepat, penuntasan/pencapaian target belajar, dan manajemen kelas.

Strategi coping yang dilakukan oleh para partisipan penelitian sebagai suatu upaya mengecilkan peluang terjadinya stres dan mengurangi dampak stres. Cara strategi coping yang dilakukan para partisipan penelitian melibatkan perilaku dan sebagian lagi melibatkan pikiran mereka. Pada saat yang sama upaya coping untuk mengatasi stres yang dilakukan mengacu pada apa yang menjadi fokus dari coping itu sendiri atau focus of coping yaitu sejauh mana coping yang dilakukan berupaya untuk mengatasi permasalahan yang ada hingga stres berkurang (problemfocused) atau mengatasi emosi yang muncul (emotion-focused) yang timbul karena stres yang dialami.

\section{Saran}

Hasil penelitian mengidentifikasi sejumlah sumber stres utama GPK di Sekolah SPK Inklusif Jagakarsa dan beberapa alternatif strategi coping guru terhadap stres yang dialaminya. Beberapa saran terkait potensi stres GPK dan bagaimana strategi coping dilakukan dikelompokkan menjadi dua bagian, yaitu saran untuk memperkecil peluang terjadinya stres dan yang kedua adalah saran untuk meminimalisasi dampak atas stres yang dialami/tidak dapat dihindari sebagai bagian dari upaya mitigasi stress terkait profesi GPK.

Untuk memperkecil peluang terjadinya stres saran atas temuan penelitian adalah:

1. Manajemen atau pimpinan sekolah disarankan untuk melakukan analisis atau evaluasi beban kerja GPK untuk melihat apakah beban kerja, rasio guru, dan kompetensi guru sesuai agar tuntutan kerja sesuai dan tidak terjadi kelebihan beban kerja yang tentunya dapat membuat GPK tidak dapat menjalankan pekerjaannya dengan baik.

2. Stres dapat terjadi karena persyaratan pekerjaan, dalam hal pengetahuan, keterampilan, dan kemampuan melebihi kemampuan seseorang yang bertanggung jawab untuk melakukan pekerjaan (Schaubroeck, Ganster \& Kemmerer, 1994). Untuk itu tim seleksi penerimaan siswa ABK baru perlu mempertimbangkan kompetensi GPK yang tersedia di tahun ajaran yang akan berjalan.

3. Sekolah perlu mengembangkan program induksi sesuai dengan kebutuhan kompetensi GPK baru terutama bagi GPK yang tidak 
memiliki latar belakang pendidikan yang linier. Materi program induksi perlu mencangkup semua pengetahuan dan ketrampilan dasar yang perlu dimiliki seorang GPK. Program induksi disarankan tidak hanya berupa paparan ceramah berisi teori-teori, namun juga disertai dengan studi kasus, dan roleplay. Bagai para guru lama yang menunjukkan kinerja yang kurang memuaskan dapat diberikan perencanaan pendampingan dan pelatihan sesuai dengan kebutuhannya. Untuk para GPK sendiri disarankan untuk proaktif melakukan pengembangan diri diluar dari program pelatihan yang diberikan oleh sekolah.

4. Hubungan kerja yang baik sangat penting dan dapat meminimalisasi konflik yang berpeluang menimbulkan stres. Oleh karena itu, para GPK perlu diberikan pelatihan tentang "Membina Hubungan di Tempat Kerja" yang termasuk di dalamnya modul tentang keterampilan komunikasi, ketrampilan bekerja dalam tim dan keterampilan soft skills yang relevan lainnya agar mampu mengembangkan sikap dan perilaku yang positif untuk membina hubungan baik dengan sesama rekan GPK. Sekolah juga dapat mengadakan kegiatan rekreasi bersama secara berkala sehingga para guru dapat lebih saling mengenal sehingga diharapkan kualitas hubungan antar guru meningkat dan bahkan menurunkan ketegangan yang ada diantara mereka.

5. Sekolah dapat mengadakan pelatihan tentang strategi mekanisme coping yang efektif yang dapat dilakukan secara berkala, agar informasi dan teknik manajemen stres yang efektif dapat dipahami oleh semua guru.

6. Sekolah perlu memberikan sesi pelatihan pada GPK tentang kondisi psikologis dan perilaku orang tua yang memiliki anak berkebutuhan khusus agar lebih dapat berempati akan situasi yang dihadapi orang tua dan implikasi yang mungkin terjadi. Sebaliknya, orang tua juga perlu diberikan edukasi tentang kondisi proses belajar mengajar di sekolah agar lebih memahami dan mendukung peran GPK dalam mendidik anak-anak mereka. Ada hal-hal atau kondisi yang tidak dapat diubah oleh GPK yang berkaitan dengan stres yang dialaminya GPK tidak dapat serta merta mengubah misalnya, jumlah dan profil siswa, bagaimana orang tua dan rekan guru bersikap, tingkat dukungan kepala sekolah, atau ketersediaan bahan ajar yang disediakan oleh sekolah. Untuk itu, para GPK perlu mempelajari dan mempraktekkan strategi coping yang telah terbukti efektif digunakan oleh rekan guru lainnya.

Saran atas temuan penelitian terkait strategi coping untuk mengurangi dampak stres kerja GPK adalah:

1. Para GPK disarankan untuk meningkatkan manajemen waktu mereka. Menuliskan daftar tugas yang perlu dilakukan pada setiap harinya dan menetapkan skala prioritas dapat meningkatkan efektifas kerja GPK.

2. Untuk kondisi atau hal-hal yang tidak dapat diubah oleh GPK seperti misalnya profil dan perilaku ABK yang sulit atau minimnya waktu 
persiapan, para GPK perlu belajar untuk menyelaraskan antara target, kondisi, dan usaha yang dilakukan. Menyesuaikan harapan (adjust the expectation) sesuai dengan kondisi yang ada dan melakukan usaha yang sesuai dengan target yang ingin dicapai disarankan untuk dilakukan.

3. Para GPK perlu bersikap proaktif dalam mencari dukungan dan bantuan yang diperlukan. Melakukan studi kasus berkala dengan rekan guru yang telah berpengalaman dapat dilakukan untuk mendapatkan masukkan dapat membantu guru menangani masalah seputar siswa ABK yang berpotensi menimbulkan stres.

4. Para GPK disarankan untuk mengembangkan beberapa kebiasaan positif untuk mengurangi dampak stres seperti:

a meluangkan waktu untuk diri sendiri (untuk melakukan hal yang dapat membuat diri bahagia dan segar kembali), meluangkan waktu untuk berolahraga, mengupayakan pola tidur yang teratur dan cukup tidur, makan makanan yang sehat, meluangkan waktu untuk keluarga dan teman-teman untuk mendapatkan dukungan, memasukkan unsur "fun" (kesenangan) ketika mengajar setiap hari, berupaya untuk selalu menampilkan sikap positif dan membiarkan segala sesuatu berjalan di luar kendali Anda, memiliki disiplin diri dalam menyelesaikan target sendiri.

5. Dalam menghadapi orang tua, GPK disarankan untuk

a Berkonsultasi pada atasan atau berdiskusi dengan rekan guru yang berpengalaman sebelum menjawab pertanyaan atau menangani perbedaan pendapat dengan orang tua.

b. Menuliskan panduan sehubungan dengan hal-hal yang perlu diutarakan pada orang tua, untuk membantu mereka dalam mengungkapkan fakta yang perlu disampaikan dan tetap fokus pada tujuan awal pertemuan. Selain itu, disarankan juga, para guru baru mendapatkan pendampingan dari atasan atau guru senior ketika mereka perlu menghadapi para orang tua untuk mendiskusikan kasus yang rumit.

6. Beberapa saran untuk sekolah adalah:

a Untuk meredakan stres karena tekanan waktu dan dinamika yang tinggi, disarankan agar tiap guru memperoleh waktu persiapan dan/atau waktu istirahat yang cukup disekolah agar tetap dapat fokus dalam menjalankan harinya. Untuk itu perlu di pikirkan pengaturan jadwal istirahat yang mutlak dapat diakses oleh guru misalnya dengan memberlakukan duty roster istirahat dalam tiap hari/minggunya. Hal seperti mengijinkan guru untuk beristirahat 10-15 menit dengan mata tertutup di siang / menjelang sore hari mungkin dapat dilakukan.

b. Menyelenggarakan sistem mentoring untuk membantu para GPK baru menjalani tugas dan tanggung jawabnya, terutama di tahun pertama mereka mengajar. 


\section{DAFTAR PUSTAKA}

Adera, B. A., \& Bullock, L. M. (2010, Vol. 15, No. 1). Job stressors and teacher job satisfaction in programs serving students with emotional and behavioral disorder. Emotional and Behavioral Difficulties, 5-14.

Alborn-yilek, S. D. (2010). Phenomenological study of Special Education Teachers Using an Emergency Lisense. Iowa: Iowa State University, Thesis and Desertation.

Amanda, B., Paula, B., \& Drummond, S. (2017). Lazarus and Folkman's Psychological Stress and Coping Theory. In The Handbook of Stress and Health: A Guide to Research and Practice, First Edition (p. 10). John Wiley \& Sons, Ltd.

Antoniou, A. S., \& Kotroni, C. (2009). Working with Students with Special Educational Needs in Greece: Teacher's Stressors and Coping Strategies. International Journal of Special Education, 100 - 111.

Ardiansyah, P. (2017). 101 Amazing Public Leadership Ideas (Pertama ed.). Bantul: Quadrant. Arismunandar, \& Ardhana, I. W. (1998). Sumbersumber Stres Kerja Guru. Jurnal Ilmu Pendidikan,

Jilid 5, Nomor 1, 3-14.

Arismunandar, \& Ardhana, I. W. (1998). Sumber-sumber Stres Kerja Guru. Jurnal Ilmu Pendidikan, Jilid 5, Nomor 1, 3-14.

Arismunandar, \& I Wayan, A. (1998). Sumber - Sumber Stress Kerja Guru. Jurnal Ilmu Pendidikan, Jilid 5, No. 1, 3.

Betoret , F. D. (2006). Stressors, Self-Efficacy, Coping Resources, and Burnout among Secondary School Teachers in Spain. Educational Psychology, 26, 519-339.

Billingsley, B. S. (2004). Special Education Teacher Retention and Attrition: A Critical Analysis of the Research Literature. The Journal of Special Education Vo. 38, No. 1, 39-55.

Blase, J. J. (1986). A Qualitative Analysis of Sources of Teacher Stress: Consequences for Performance. American Educational Research Journal, Vol. 23, 13-40.

Brooks, I. (2006). Organisational Behaviour (Third ed.). Essex, England: Pearson Education Limited. Cancio, E. J., Larsen, R., Mathur, S. R., Estes, M. B., Johns, B., \& Chang, M. (2018 ). Special Education Teacher Stress : Coping Strategies. Education and Treatment of Children, Vol. 41, No. 4, 451-476.

Cemal Zehir, O. G. (2011). International Strategic Management Conference. 24 1460-1475. Istanbul: Procedia Social \&Bbehavioral Sciences, Elsevier Ltd.

Cohen, L., Manion, L., \& Morrison, K. (2007). Research Methods in Education (Keenam ed.). Oxon: Routledge.

Colquitt, J. A., Lepine, J. A., \& Wesson, M. J. (2015). Organizational Behavior : Improving Performance in the Workplace. USA: McGraw-Hill Education.

Creswell, J. W. (2008). Educational Research Planning, Conducting and Evaluating Quantitative and Qualitative Research (Third ed.). New Jersey 07458, USA: Pearson Education, Inc.

Creswell, J. W. (2014). Research Design. Qualitative, Quantitative, and Mixed 
Methods Approaches.

London: SAGE Publication Ltd.

Dganit, H., \& Bocos, M. (2015). The Development of a Sense of COherence In Teaching Situation Among Special Education Pre-Service Teachers . Social and Behavioral Science , 209, 240- 246.

Direktorat PPK-LK \& Pendidikan Dasar. (2011). Pedoman Umum Penyelenggaraan Pendidikan Inklusif. Jakarta: Kementrian Pendidikan dan Kebudayaan.

Dunham, J. (1992). Stress in Teaching . London: Routledge.

Emery, D. W., \& Vadenberg, B. (2010). Special Education Teacher Burnout and ACT. International Journal of Special Education, 199-131.

Fraenkel, J. R., \& Wallen, N. E. (2008). How to Design and Evaluate Research in Education (Pertama ed.). New York: McGraw-Hill.

Ghani, M. Z., Ahmad, A. C., \& Ibrahim, S. (2014). Stress among Special Education Teachers in Malaysia. Procedia - Social and Behavioral Sciences 114, 4-13.

Griffin, R., \& Moorhead, G. (2014). Organizational Behavior: Managing People and Organization.

USA: South-Western Cengage Learning.

Guglielmi, R. S., \& Tatrow, K. (1998). Occupational Stress, Burnout, and Health in Teachers: A Methodological and Theoretical Analysis. Review of Educational Research, 61-69.

Hartney, E. (2008). Stres Management for Teachers . London: Continuum International Publishing Group .

Hartney, E. (2008). Stress Management For Teachers. London, New York: Continum International Publishing Group.

Hayes, C. (2006). Stress Relief for Teachers. The 'Coping Triangle'. Taylor \& Francis e-Library. Hughes, R. L., Ginnett, R. C., \& Curphy, G. J. (2006). Leadership Enhancing the Lessons of

Experiences (Kelima ed.). New York: The McGraw-Hill Companies, Inc.

Indrawan, R., \& Yaniawati, P. (2014). Metodologi Penelitian Kuantitatif, Kualitatif dan Campuran untuk Manajemen, Pembangunan dan Pendidikan (Kedua ed.). (N. F. Atif, Ed.) Bandung, Jawa Barat, Indonesia: PT Refika Aditama.

Indrawan, R., \& Yaniawati, P. (2016). Metodologi Penelitian Kuantitatif, Kualitatif, dan Campuran untuk Manajemen, Pembangunan, dan Pendidikan. Bandung: PT Refika Aditama.

Kaswan. (2018). Perilaku Organisasi Positif. Bandung, Jawa Barat, Indonesia: Pustaka Setia. Kementrian Pendidikan dan Kebudayaan. (2019). Tanya Jawab Seputar Pembinaan Guru. Jakarta:

Direktorat Jendral Guru dan Tenaga Kependidikan.

Lazarus, R. S., \& Folkman, S. (1984). Stress, Appraisal and Coping. New York : Springer Publishing Company, Inc.

Lee, R., \& Ashforth, B. (1996). A Meta-Analytic Examination of the Correlates of the Tree Dimensions of Job Burnout. Journal of Applied Psychology, vol. 81, no. 2, 123 - 133.

Linkert, R. (1967). The Human Organizational: Its Management and Value (First ed.). New York: McGraw-Hill Book company. 
Machali, I., \& Hidayat, A. (2016). The Handbook of Education Management (Ke-1 ed.). Jakarta: Prenaadamedia Group.

Macik-Frey, M., Campbell Quick, J., \& Nelso, D. (2007, vol 33. no. 6). Advances in Occupational Health: From A Stressful Beginning to a Positive Future. Journal of Management, 809 - 840.

McShane, S. L., \& Glinow, M. V. (2018). Organizational Behavior: Emerging Knowledge. Global Reality. New York: McGraw-Hill Education.

Metereko, S. (2014 Vol 5 No 27). Sink or Swim: Teachers' Stress Coping Mechanism in a Sout African School. Mediterranean Journal of Social Sciences, 698 -710.

Mondy, R. W. (2008). Manajemen Sumber Daya Manusia. Erlanggga.

Morrow, R., Rodriguez, A., \& King, N. (2015). Colaizzi's Descriptive Phenomenological Method .

The Psychologist, 643-644.

Mullins, L. J. (2005). Management \& Organization Behaviour (Ketujuh ed.). Essex, England: Pearson Education Limited.

Pilhie, Z., \& Sadeghi, A. (2011). Analysis of Head of Departments Leadership Styles: Implication for Improving Research University Management Practices. Procedia, 1081-1090.

Priansa, D. J. (2017). Manajemen Kinerja Kepegawaian. Bandung: CV Purtakaa Set.

Priansa, D. J. (2017). Manajemen Kinerja Kepegawaian: dalam Pengelolaan SDM Perushaan.

Bandung: Pustaka Setia.

Pulakos, E. D. (2004). Performance Management A Roadmap for Developing, Implementing \& Eavaluating Performance Management System. SHRM Foundation.

Pulakos, E. D. (2009). Performance Management A new Approach for Driving Business Results.

Sussex, UK: Wiley-Blackwell.

Purwanto, E. A., \& Sulistyastuti, D. R. (2017). Metode Penelitian Kuantitatif (Pertama ed.).

Yogyakarta: Gava Media.

Purwanto, N. (1994). Ilmu Pendidikan Teoritis dan Praktis . Bandung: Remaja Rosdakarya.

Rabenu, E., \& Yanif, E. (2017). Psychological Resources and Strategies to Cope with Stress at Work.

International Journal of Psychological Research, 8.

Ramsey, R. D. (1996). The Principal's Book of Lists. Joss ey-Bass.

Rangkuti, F. (2014). Analisis SWOT : Teknik Membedah Kasus Bisnis. Jakarta: PT Gramedia Pustaka Utama.

Rasmun. (2004). Stres, Koping dan Adaptasi. Sagung Seto.

Richards, J. (2012). Teacher Stress and Coping Strategies: A National Snapshot. The Educational Forum, 76: 299-316.

Ricky W, G., \& Gregory, M. (2014). Organizational Behavior: Managing People and Organization.

USA: South-Western Cengage Learning.

Robbins, S. P., \& Coulter, M. (2012). Management (11 ed.). New Jersey: 
Pearson Education Inc. Robbins, S. P., \& Judge, T. (2013).

Organizational Behavior. New Jersey: Pearson Education.

Robbins, S. P., \& Judge, T. A. (2017). Organizational Behavior (Ketujuh belas ed.). Essex, England: Pearson Education Limited.

Rohiat, M. P. (2012). Manajemen Sekolah Teori Dasar dan Praktik. Bandung: Refika Aditama.

S. D, G. (2003). Dasar dan Teori Perkembangan Anak. BPK Gunung Mulia.

Santoso, E., \& Setiawan, J. L. (2018). Peran Dukungan Sosial Keluarga, Atasan, dan Rekan Kerja terhadap Resilient Self-Efficacy Guru Sekolah Luar Biasa. Jurnal Psikologi, Volume 45, Nomor 1, 27 - 39.

Schein, E. H. (2004). Organizational Culture and Leadership. San Francisco, CA: Jossey - Bass, A Wiley Imprint.

Sedarmayanti. (2014). Manajemen Strategi. Bandung: Refika Aditama.

Skaalvik, E. M., \& Skaalvik, S. (2015). Job Satisfaction, Stress and Coping Strategies in the Teching Profession - What Do Teachers Say? International Education Studies, Vol. 8, No. 3, 181 - 192. Strydom, L., Nortje, N., Beukes, R., Esterhuyse, K., \& Wethuizen, J. v. (2012). Job Satisfaction amongst Teachers at Special Needs Schools. South African Journal of Education, Vol. 3, 255-266.

Sudaryono. (2014). Budaya \& Perilaku Organisasi (Pertama ed.). Jakarta: Lentera Ilmu Cendekia Perkantoran Sentra.

Sugiono. (2015). Metode Penelitian Manajemen Pendekatan Kuantitatif, Kualitatif, Kombinasi, Penelitian Tindakan, Penelitian Evaluasi. Bandung: Alfabeta.

Sugiyono. (2016). Metode Penelitian Manajemen (Kedelapan ed.). Bandung: Alfabeta.

Sunu, I. g. (2014). Studi Kebijakan Nasional: Kajian Terhadap Kebijakan Pendidikan. Yogyakarta: Graha Ilmu.

Suwartono. (2014). Dasar-dasar Metodologi Penelitian. Yogyakarta: Penerbit Andi.

Tarnoto, N. (2016). Permasalahan-Permasalahan Yang Dihadapi Sekolah Penyelenggara Pendidikan Inklusi Pada Tingkat SD. 13.

Tarnoto, N. (n.d.). Permasalahan-permasalahan yang Dihadapi Sekolah Penyelenggara Pendidikan Inklusi pada Tingkat SD. Humanitas, Vol. 13 No. $1,50-61$.

Thoyib, A. (2005). Hubungan Kepemimpinan, Budaya, Strategi dan Kinerja: Pendekatan Konsep.

Jurnal Manajemen \& Kewirausahaan, 7 No.1.

Triatna, C. (2016). Perilaku Organisasi dalam Pendidikan. Bandung, Jawa Barat, Indonesia: Remaja Rosdakarya.

Troesch, L. M., \& Bauer, C. E. (2017). Second career teachers: Job satisfaction, job stress, and the role of self-efficacy. Teaching and Teacher Education, $389-398$.

Umar, A. (2015). The Effects of Motivation and Carrer Development Againts Employee's Performance and Job Satisfaction of the Governor Office South Sulawesi Province. International Journal of Management Sciences, 5 No. 9, 628-638.

VanSlyke-Briggs, K. (2010). The Nurturing Teacher: Managing the Stress of 
Caring. United Kingdom: Rowman \& Littlefield Education.

Vittek, J. E. (2015). Promoting Special Educator Teacher Retention: A Critical Review of the Literature. SAGE, 1-6.

Wibowo. (2013). Perilaku Dalam Organisasi (3 ed.). Depok, Jawa Barat, Indonesia. Rajagrafindo Persada.

Wibowo. (2016). Budaya Organisasi: Sebuah Kebutuhan untuk Meningkatkan Kinerja Jangka Panjang (Keempat ed.). Jakarta: Rajawali Pers.

Wibowo. (2016). Manajemen Kinerja. Jakarta: Rajawali Pres.

Wibowo. (2017). Perilaku Dalam Organisasi (3 ed.). Depok, Jawa Barat, Indonesia: Rajawali Pers.

Zainal, V. R., Hadad, M. D., \& Ramly, M. (2014). Kepemimpinan dan Perilaku Organisasi (Ke-11 ed.). Depok: RajaGrafindo Persada.

Zainal, V. R., Hadad, M. D., \& Ramly, M. (2017). Kepemimpinan dan Perilaku Organisasi (4 ed.). Depok: Rajawali Pers. 